\title{
Epizoic acoelomorph flatworms compete with their coral host for zooplankton
}
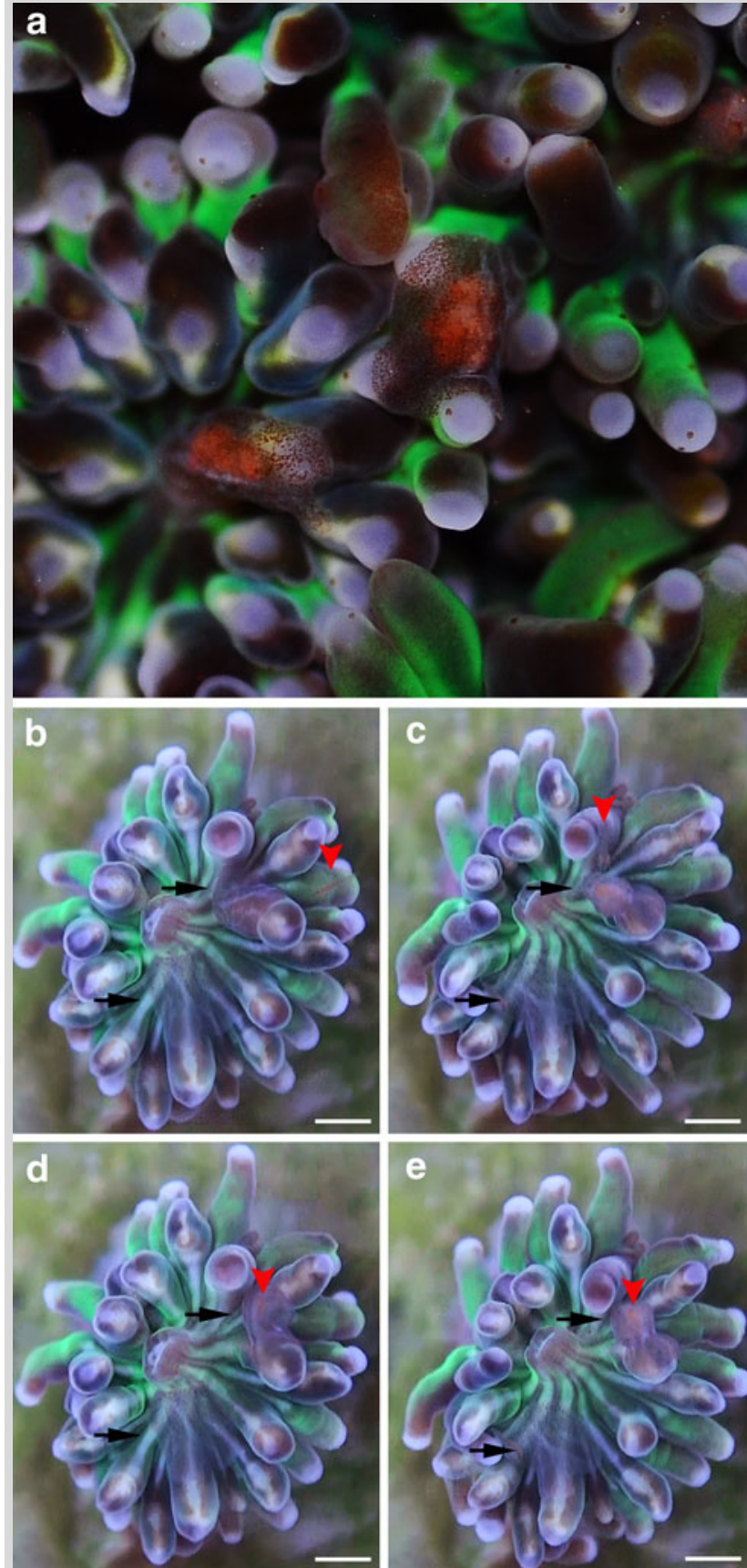

Fig. 1 Epizoic acoelomorph flatworms hosted by Galaxea fascicularis (a). Time lapse photography of a flatworm capturing a single Artemia nauplius (b-e) Black arrows indicate flatworms, red arrowheads indicate nauplius. Scale bars $500 \mu \mathrm{m}$
It is well known that many scleractinian coral species host epizoic acoelomorph flatworms, both in captivity and in situ, with potential negative effects such as light-shading and reduced resistance against environmental impacts and pathogens (Naumann et al. 2010). Here, we show that epizoic acoelomorph flatworms (Waminoa sp.) compete with their coral host for zooplankton under laboratory conditions.

Single polyps $(\mathrm{n}=5)$ of the scleractinian coral Galaxea fascicularis were incubated in a flow cell for $30 \mathrm{~min}$ together with Artemia nauplii $\left(10,000 \mathrm{~L}^{-1}\right)$, and their feeding activities were recorded.

On average, $G$. fascicularis polyps hosted $2 \pm 1 \mathrm{SD}$ flatworms which captured a total of $1.7 \pm 0.5 \mathrm{SD}$ Artemia nauplii per $30 \mathrm{~min}$ interval $\left(0.9 \pm 0.6 \mathrm{SD}\right.$ nauplii flatworm $\left.{ }^{-1}\right)$. Flatworms captured nauplii by raising their anterior edge from the polyp surface, curling their lateral edges downward and encapsulating prey (Fig. 1a-e, supplemental

video). Subsequent paralysis of prey was observed, which was possibly followed by ingestion and digestion of prey. Similar predatory behavior has been documented for the flatworm Convolutriloba retrogemma (Hendelberg and Åkesson 1988). Translocation of Artemia nauplii or partially digested remnants thereof from the flatworms to the coral host was not observed in this study, indicating that the flatworms compete for food with their coral host.

Although the competitive pressure exerted by flatworms may seem moderate when taking the host feeding rate in the laboratory ( $52.8 \pm 41.9$ nauplii polyp ${ }^{-1} 30 \mathrm{~min}^{-1}$ ) into account, it could be significant at in situ plankton concentrations which are four orders of magnitude lower than those used here (Palardy et al. 2006). We conclude that the presence of epizoic acoelomorph flatworms may affect long-term coral growth and health.

These results have implications for our understanding of coral host-symbiont interactions and benthic-pelagic coupling.

Acknowledgments This work was funded by Wageningen University

Open Access This article is distributed under the terms of the Creative Commons Attribution Noncommercial License which permits any noncommercial use, distribution, and reproduction in any medium, provided the original author(s) and source are credited.

\section{References}

Hendelberg J, Åkesson B (1988) Convolutriloba retrogemma gen. et sp.n., a turbellarian (Acoela, Platyhelminthes) with reversed polarity of reproductive buds. Fortschr Zool 36:321-327

Naumann MS, Mayr C, Struck U, Wild C (2010) Coral mucus stable isotope composition and labeling: experimental evidence for mucus uptake by epizoic acoelomorph worms. Mar Biol 157:2521-2531

Palardy JE, Grottoli AG, Matthews KA (2006) Effect of naturally changing zooplankton concentrations on feeding rates of two coral species in the Eastern Pacific. J Exp Mar Biol Ecol 331:99-107

Electronic supplementary material The online version of this article (doi:10.1007/s00338-011-0781-z) contains supplementary material, which is available to authorized users.

T. Wijgerde $(\bowtie) \cdot$ P. Spijkers $\cdot$ J. Verreth $\cdot$ R. Osinga Department of Animal Sciences, AFI, Wageningen UR, Marijkeweg 40, 6709 PG Wageningen, The Netherlands e-mail: tim.wijgerde@wur.nl

Received: 10 March 2011/ Accepted: 16 April 2011/Published online: 16 June 2011

Coral Reefs (2011) 30:665

(C) The Author(s) 2011. This article is published with open access at Springerlink.com 